DOI $10.15421 / 4221001$

УДК 539.3

В. М. Бистров, канд. фріз.-мат. наук, В. А. Декрет, д-р фріз.-мат. наук, В. С. Зеленський, канд. фріз.-мат. наук

\title{
КРАЙОВИЙ ЕФЕКТ У ШАРУВАТОМУ КОМПОЗИТНОМУ МАТЕРІАЛІ ПРИ НЕДОСКОНАЛОМУ КОНТАКТІ МІЖ ШАРАМИ
}

Із застосуванням рівнянь теорії пружності кусково-однорідних тіл та кількісного критерію згасання крайового ефекту досліджено крайовий ефект у околі поверхневого навантаження шаруватого композитного матеріалу. Розглянуто випадок недосконалого контакту між шарами, який моделюється періодичною системою міжшарових тріщин у вигляді математичного розрізу. Використана розрахункова модель для граничних умов на бічних сторонах багатошарового зразка 3 композитного матеріалу, які відповідають умовам симетрії. Досліджено вплив розміру тріщин на довжину згасання крайового ефекту. Для числового розв'язування задачі використано метод сіток на основі модифікованого варіаційно-різницевого підходу. В рамках обчислювального експерименту застосовані послідовний i паралельний алгоритм методу Холецького для розв'язання системи лінійних алгебраїчних рівнянь.

Ключові слова: шаруватий композитний матеріал; недосконалий контакт; поверхневе навантаження, крайовий ефрект; плоска задача теорії пружності; кількісний критерій згасання крайового ефректу; метод сіток; паралельні обчислення.

Вступ. При проєктуванні, розрахунку та випробуванні композитних матеріалів (КМ) становить інтерес дослідження спільного впливу на крайові ефекти таких факторів, як структурна неоднорідність КМ і зовнішні умови навантаження та закріплення елементів конструкцій з КМ. У багатьох роботах, пов'язаних 3 дослідженням впливу неоднорідності КМ на згасання крайових ефектів, відзначається, що протяжність зони крайових ефектів при певному співвідношенні пружних і геометричних властивостей компонент матеріалу може досягати великих значень $[1,2,6,8-11,16-19]$. Це накладає істотне обмеження на традиційне застосування принципу Сен-Венана при проєктуванні і розрахунку конструкцій з КМ. Ослаблення адгезії між компонентами КМ внаслідок таких дефектів, як непроклеі та розшарування, тріщини тощо, може призвести до подальшого зменшення швидкості згасання крайового ефекту у області дії локального навантаження $[6,7,17,18]$.

Оскільки при експлуатації елементів конструкцій з КМ силові навантаження, як правило, направляють уздовж армуючих елементів, найбільш актуальним $€$ питання про згасання крайових ефектів при дії локального навантаження у цьому напрямку. Характер згасання крайового ефекту, геометрія його зони, розподіл полів напружень i

() В. М. Бистров, В. А. Декрет, В. С. Зеленський, 2021 
деформацій в зоні крайового ефекту залежать від співвідношення геометричних параметрів, які характеризують область зміни зовнішнього навантаження і структурну неоднорідність матеріалу [8, 9, 13]. При цьому найбільший інтерес представляє випадок поверхневого навантаження, коли його суттєва зміна відбувається на відстанях, порівнянних з характерним розміром структурної неоднорідності КМ. Це, зокрема, відповідає випадку поверхневого навантаження тільки армуючих компонентів КМ. Іншим фактором, який впливає на характер і швидкість згасання крайового ефекту при торцевому навантаженні КМ, $€$ граничні умови на бічних сторонах розрахункових областей при моделюванні проблеми визначення крайових ефектів на основі рівнянь та методів теорії пружності неоднорідних тіл у двовимірній постановці (плоска та антиплоска деформація). Так, у порівнянні із випадком вільних від напружень бічних сторін зразку з КМ накладання додаткових зв'язків у вигляді змішаних граничних умов або умов у переміщеннях на бічних сторонах розрахункової області, які включають кінематичні умови по одній або двом складовим, призводить до зменшення зони крайового ефректу. При цьому перерозподіл зовнішнього навантаження між компонентами КМ для різних граничних умов може призвести до оберненого характеру залежності (інверсії) довжини згасання крайового ефекту у компонентах КМ від співвідношення їх пружних і геометричних властивостей [6, 9]. Подібна інверсія відбувається і при ослабленні адгезії між шарами, яке відповідає найменш жорсткому їх з'єднанню проковзуванню [7]. Слід зазначити, що випадок змішаних граничних умов $€$ найменш дослідженим при тому, що цей вид умов найбільш адекватно відповідає композитним матеріалам, які моделюються нескінченними або напівнескінченними областями і згасання крайового ефекту досліджується на елементі періодичності композитної структури $[8,18,19]$.

Порушення адгезії між компонентами КМ за наявністю міжшарових десектів також відповідає звільненню від зв'язків у порівнянні 3 ідеальним контактом для усіх видів граничних умов i потребує проведення досліджень щодо характеру та кількісної оцінки зменшення швидкості згасання крайового ефекту. При моделюванні недосконалого контакту між компонентами КМ найбільш поширеним підходом $є$ застосування моделей типу моделі пружинного шару (spring-layer model) $[6,7,17]$, коли вздовж усієї лінії контакту задається пропорційний зв'язок між стрибком переміщень і тангенціальними зусиллями на контакті. Інший підхід може полягати у застосуванні на ділянках лінії контакту компонентів КМ граничних умов, які відповідають ідеальному з'єднанню шарів та дефектам міжшарової адгезії різної природи. Дефекти, зокрема, можуть бути представлені або тріщинами з вільними від зусиль берегами або “дефектами із зв'язаними берегами", які відповідають умовам проковзування, коли умова неперервності зберігається лише для нормальних компонент переміщень і напружень $[15,18]$. 
У даній роботі досліджується у двовимірній постановці вплив недосконалого контакту на згасання крайового ефекту у шаруватому композитному матеріалі для багатошарового представницького елементу з умовами симетрії на бічних сторонах розрахункової області. Застосовується підхід, який заснований на використанні співвідношень теорії пружності неоднорідних тіл і кількісних критеріїв оцінки крайового ефекту для представницького елементу КМ [8]. Недосконалий контакт між центральним армуючим шаром і матрицею моделюється системою міжшарових макротріщин 3 вільними від зусиль берегами. Макротріщинами вважаються тріщини, довжина яких $є$ порівняною або перевищує товщину армуючих шарів КМ.

Для числового розв'язування задачі використано метод сіток на основі модифікованого варіаційно-різницевого підходу $[2,3]$. В рамках обчислювального експерименту для розв'язання системи лінійних алгебраїчних рівнянь великої розмірності застосовані послідовний і паралельний алгоритм методу Холецького [5].

Постановка задачі. Розглянемо задачу визначення параметрів згасання крайового ефекту для двокомпонентного КМ регулярної структури за наявністю недосконалого контакту між шарами (рис. 1, а) для схеми навантаження, яка відповідає одноосьовому стисканню шарів наповнювача в напрямку осі $O x_{2}$ поверхневим навантаженням постійної інтенсивності $p^{0}$ і призводить до неоднорідного напруженодеформівного стану у околі навантаження (статичного крайового ефекту). Це навантаження має такий вигляд:

$$
p\left(x_{1}\right)=\sigma_{22}\left(x_{1}, 0\right)=\left\{\begin{array}{cc}
p^{0}, & -h_{a} / 2+k h \leq x_{1} \leq h_{a} / 2+k h, k=0, \pm 1, \ldots, \\
0, & \text { для інших } x_{1} .
\end{array}\right.
$$

де $h=h_{a}+h_{m}$ - параметр структури шаруватого $\mathrm{KM}, h_{a}, h_{m}$ відповідно товщина шару наповнювача (армуючого шару) i шару зв'язуючого (матриці).

Припускаємо, що на нескінченності навантаження до армуючих шарів прикладається за такою ж схемою. Уздовж осі $O x_{3}$ навантаження не змінюється. Виходячи з умов симетрії навантаження і регулярності структури КМ, задачу визначення зони (довжини згасання) крайового ефекту розв'язуємо для представницького елемента матеріалу, якому відповідає розрахункова область скінченних розмірів. На підставі результатів $[1,13]$ розмір цієї області в напрямку осі $O x_{1}$ відповідає періоду $b$ поверхневого навантаження і складає $l_{1}=b / 2=8 h$. Розмір у напрямку $O x_{2}$ встановлюється за результатами обчислювального експерименту і повинний відповідати умові сталого значення параметрів згасання крайового ефекту при подальшому зростанні вказаного розміру. Зазначена розрахункова область показана на рис. 1 , б. Тут 
введено позначення: сим 1, сим2, сим 3 - вісі симетрії $x_{1}=0, x_{1}=l_{1}$, $x_{1}=l_{2}$ відповідно. Вважаємо, що для такої геометрії розрахункової області і умов навантаження згасання крайового ефректу набуває сталого характеру щодо подальшого збільшення періоду навантаження і отримані результати будуть відповідати КМ, який моделюється напівнескінченною областю. Крайні шари представницького елемента $€$ армуючими шарами. Граничні умови на бічних сторонах розрахункової області відповідають умовам симетрії.

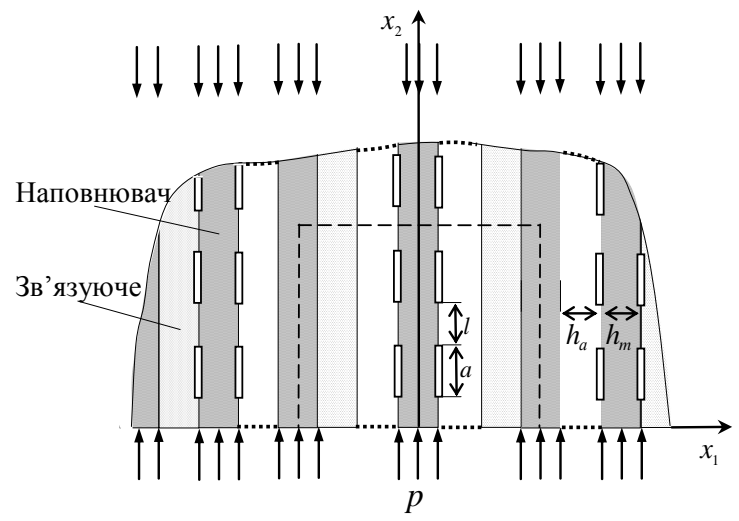

a)

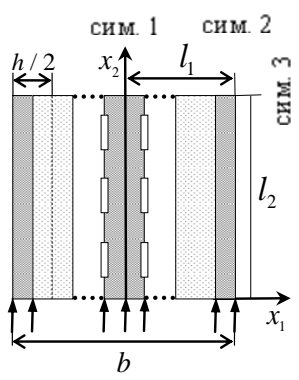

б)

Рис. 1 - Схема двокомпонентного КМ:

a) - шаруватий КМ із недосконалим контактом між армуючими шарами і матрицею; б) - представницький елемент матеріалу

Розрахункова схема для визначення зони (довжини згасання) крайового ефекту включає двовимірну (плоска деформація) крайову задачу теорії пружності кусково-однорідних тіл і кількісний критерій визначення крайового ефекту із застосуванням функції згасання напружень [8]. Розглядається випадок самоврівноваженого навантаження, яке отримується шляхом суперпозиції поверхневого навантаження i нормальних напружень для сталого напруженодеформівного стану при згасанні крайового ефекту.

Напружено-деформівний стан із урахуванням симетрії навантаження визначаємо із наступних основних співвідношень лінійної теорії пружності для області $\bar{\Omega}=\left\{\left(x_{1}, x_{2}\right) \mid 0 \leq x_{1} \leq l_{1} ; 0 \leq x_{2} \leq l_{2}\right\}$ :

- рівняння рівноваги

$$
\sigma_{i j, i}=0 \quad x \subset \bar{\Omega}
$$

- граничні умови 


$$
\begin{gathered}
\sigma_{21}=0 \wedge u_{2}=0,0 \leq x_{1} \leq l_{1} \wedge x_{2}=l_{2} \\
\sigma_{12}=0 \wedge u_{1}=0,\left(x_{1}=0 \vee x_{1}=l_{1}\right) \wedge\left(0 \leq x_{2} \leq l_{2}\right) \\
\sigma_{22}=p \wedge \sigma_{21}=0,0 \leq x_{1} \leq l_{1} \wedge x_{2}=0
\end{gathered}
$$

- умови ідеального контакту на границі між компонентами КМ

$$
\left[n_{i} \sigma_{i j}\right]=0,\left[u_{i}\right]=0
$$

- умови недосконалого контакту на ділянках границі між центральним армуючим шаром і матрицею, які відповідають наявності на межі розділу компонент КМ математичних розрізів із вільними від напружень сторонами

$$
n_{i} \sigma_{i j}^{a}=0, n_{i} \sigma_{i j}^{m}=0
$$

- $\quad$ співвідношення між компонентами напружень $\sigma_{i j}$, деформацій $\varepsilon_{i j}$ и переміщень $u_{i}$ у межах компонента КМ

$$
\sigma_{i j}=\delta_{i j} A_{i k} \varepsilon_{k k}+2\left(1-\delta_{i j}\right) G \varepsilon_{i j}, \varepsilon_{i j}=\frac{1}{2}\left(u_{i, j}+u_{j, i}\right), i \neq j,
$$

де

$$
A_{11}=A_{22}=\frac{E(1-v)}{(1+v)(1-2 v)}, A_{12}=\frac{E v}{(1+v)(1-2 v)}, G=\frac{E}{2(1+v)}
$$

Границю зони $\Gamma_{\rho}$ и довжину згасання $\lambda_{\rho}$ крайового ефректу 3 точністю $\rho(\%)$ визначаємо із наступних співвідношень [8]:

$$
\begin{aligned}
& \rho=\left.\tilde{\rho}\left(x_{1}, x_{2}\right)\right|_{x \in \Gamma}, \\
& \lambda_{\rho}=\max _{x_{1}, x_{2} \in \Gamma_{\rho}}\left(x_{2}\right),
\end{aligned}
$$

де фуункція згасання напружень $\tilde{\rho}\left(x_{1}, x_{2}\right)$ визначається співвідношенням

$$
\tilde{\rho}=100\left(\sigma_{22}(x)-\sigma_{y c m}\right) /\left(p\left(x_{1}, 0\right)-\sigma_{y c m}\right) .
$$


Функція $\tilde{\rho}\left(x_{1}, x_{2}\right)$ характеризує зміну нормальних напружень в зоні крайового ефректу у порівнянні із значенням самоврівноваженого навантаження на границі $x_{2}=0$ розрахункової області. В (10) $\sigma_{y c m}=\sigma_{22}\left(x_{1}, l_{2}\right)$ - усталене нормальне напруження на границі $x_{2}=l_{2}$ розрахункової області у напрямку згасання крайового ефекту.

В (6), (7) $A_{i j}, E, G, v$ - модулі пружності, модуль Юнга, модуль зсуву, коефіцієнт Пуасона компоненти КМ відповідно.

Позначення в (1) - (8) є загальноприйнятим, індекси змінюються від 1 до 2 ( $\wedge, \vee$ - знаки логічного множення и додавання). Індекс, який позначає належність до компоненти КМ у співвідношеннях (2) - (4), (6), (7) для зручності не застосовується. У співвідношеннях (4), (5) $n_{i}$ - орти зовнішньої нормалі до поверхні, $[f(x)]=f(x-0)-f(x+0)-$ стрибок фрункції $f(x)$.

Числовий розв'язок. Задачі (2) - (7) розв'язані методом сіток із застосуванням концепції базової схеми [2, 3]. Для розв'язування дискретних задач застосовані ефективні числові методи. Алгебраїчна задача визначення напружено-деформованого стану розв'язувалася прямим методом Холецького, а після згущення різницевої сітки застосовувався ітераційний метод спряжених градієнтів [5, 14]. При проведенні обчислювального експерименту для отримання розв'язку систем лінійних алгебраїчних задач великої розмірності методом Холецького застосовувалось паралельне програмне забезпечення [5]. Розрахунки проводились на обчислювальному вузлі суперкомп'ютера CKIT [4] (один обчислювальний вузол, два восьмиядерних процесора серії Xeon E5 2600, 2 GPU Tesla M2075). Оцінка ефрективності застосованого алгоритму $\epsilon$ порівняною із результатами для числового дослідження докритичного стану КМ, армованих короткими волокнами [12].

Аналіз числових результатів. Результати отримані для розрахункової моделі, представленої на рис. 1, б. Розрахунки були проведені для наступних механічних та геометричних характеристик КМ (індекс "a" відноситься до армуючого шару, індекс " $m$ "- до матриці): відношення модулів Юнга армуючих шарів і матриці $E_{a} E_{m}^{-1}=100,1000$; коефіцієнти Пуассона $v_{a}=v_{m}=0,3$; довжини макротріщин складали $a=h, 2 h, 3 h$, де $h=h_{a}+h_{m}$. Розмір розрахункової області у напрямку осі $O x_{2}$, визначений за результатами обчислювального експерименту, становив $l_{2}=20 l_{1}=160 h$.

На рис. 2 показано поведінку фрункції згасання напружень $\tilde{\rho}\left(0, x_{2}^{*}\right)=\tilde{\rho}\left(0, x_{2} / h\right)$, заданою співвідношенням (10), у армуючому шарі для діапазонів $\rho=20 \div 5 \%$ (рис. 2, а, в) і $\rho=5 \div 1 \%$ (рис. 2, б, г) 
згасання крайового ефекту. Довжина $\lambda_{\rho}$ згасання крайового ефекту, для якої значення нормального напруження при згасанні крайового ефекту складає $\rho$ відсотків від значення самоврівноваженого поверхневого навантаження, визначається як така, що дорівнює відповідному значенню $x_{2}^{*}$.

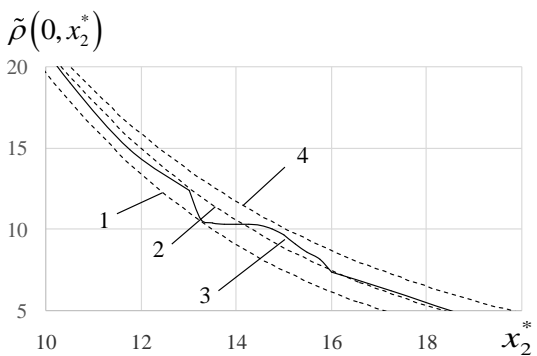

a)

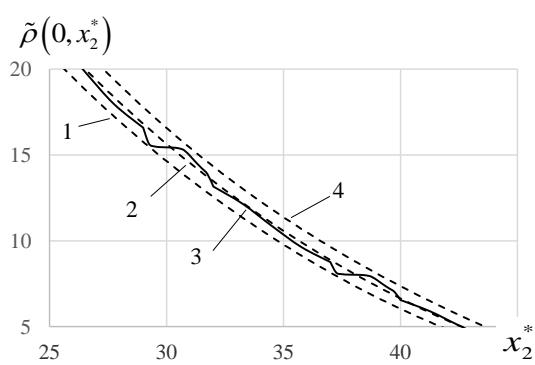

B)

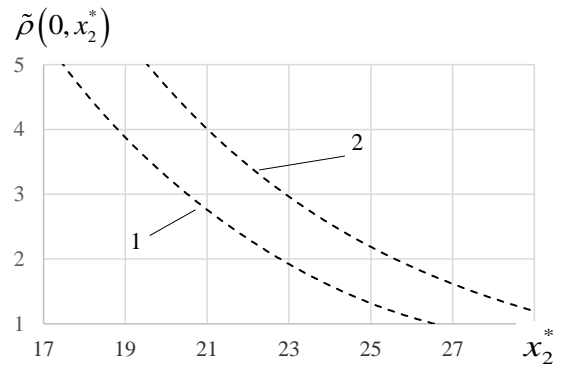

б)

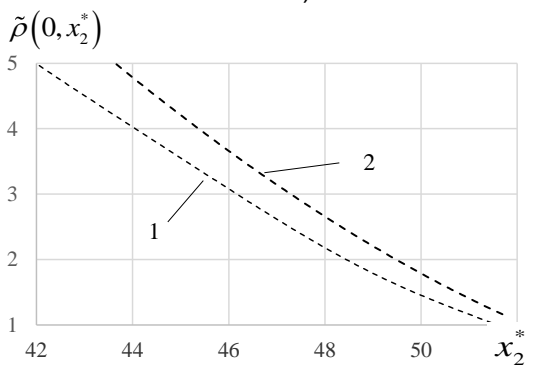

2)

Рис. 2 - Функції згасання напружень у середньому армуючому шарі представницького елементу КМ при ідеальному і недосконалому контакті:

$$
\text { а), б) - для } E_{a} / E_{m}=100 \text {; в), г) - для } E_{a} / E_{m}=1000
$$

На рис. 2, а, в криві 1 відповідають ідеальному контакту, криві 2, 4 недосконалому контакту при довжині тріщин $a=2 h$ i $a=3 h$. На рис. 2, б, г криві 1 відповідають ідеальному контакту, криві 2 - недосконалому контакту при довжині тріщин $a=3 h$. Наведені залежності для більш сприйнятливої візуалізації результатів представлені згладженими кривими шляхом їх інтерполяції (лінії тренду EXCEL, які відповідають поліному 6 ступеня). Вихідні залежності показані тільки на рис. 2, a, в для значення $a=2 h$ (суцільні лінії).

Із наведеної графрічної інформації видно, що при ослабленні адгезії внаслідок наявності тріщин і збільшенні їх розміру довжина згасання крайового ефекту $\lambda_{\rho}$ зростає. Так, довжина $\lambda_{\rho=5 \%}$ згасання крайового ефекту при ідеальному і недосконалому $(a=3 h)$ контакті відповідно 
складає: $17,4 h$ і $19,47 h$ для $E_{a} / E_{m}=100,42 h$ і $43,4 h$ для $E_{a} / E_{m}=1000$. Збільшення відношення $E_{a} / E_{m}$ призводить до збільшення довжини згасання крайового ефекту як при ідеальному контакті, так і при недосконалому, але у разі більш жорстких армуючих шарів таке збільшення $є$ менш значним.

Висновки. Отримані результати дозволяють зробити наступні висновки.

1. Моделювання недосконалого контакту шляхом застосування граничних умов на ділянках контакту компонентів КМ, які відповідають дефектам міжшарової адгезії у вигляді макротріщин з вільними від зусиль берегами, дозволяє досліджувати вплив ослаблення адгезії на швидкість згасання крайового ефекту.

2. Наявність недосконалого контакту і послаблення адгезії при збільшенні розміру макротріщин призводить до збільшення довжини згасання крайового ефекту та більш повільному його згасанню.

\section{БИБЛІОГРАФІЧНІ ПОСИЛАННЯ}

1. Быстров В. М. Краевой эффект и приповерхностная потеря устойчивости в слоистом композитном материале при сжатии поверхностной нагрузкой // Доп. Нац. акад. наук Укр. 2019. № 10. С. 29-37.

2. Головчан В.Т., Гузь А.Н., Коханенко Ю.В., Кущ В.И. Статика материалов. Механика композитов: в 12 т. / Под общей ред. А.Н. Гузя. Т.1. К.: Наукова думка, 1993. $455 \mathrm{c}$.

3. Григоренко Я.М., Шевченко Ю.В., Василенко А.Т. и др. Численные методы. Механика композитов: В 12-и т. / Под общей ред. А.Н. Гузя. Т.11. К.: «А.С.К.», 2002. $448 \mathrm{c}$.

4. Суперкомп'ютер ІК НАН України. http://icybcluster.org.ua/.

5. Химич А.Н., Молчанов И.Н., Попов А.В., Чистякова Т.В., Яковлев М.Ф. Параллельные алгоритмы решения задач вычислительной математики. К.: Наукова думка 2008. 247 с.

6. Baxter S.C., Horgan C.O. End Effects for Anti-plane Shear Deformation of Sandwich Structure // J. of Elasticity. 1995. Vol. 40. No. 2. P. 123-164.

7. Benveniste $Y$. On the Effect of Debonding on the Overall Behavior of Composite Materials // Mech. Mater. 1984. Vol. 3. P. 349-358.

8. Bystrov V.M. Analysis of the decay of edge effects in laminated materials on the basis of a representative element // Int. Appl. Mech. 2000. Vol. 36. No 6. P. 826-834.

9. Bystrov V.M., Dekret V.A., Zelenskii V.S. Numerical Analysis of the Edge Effect in a Composite Laminate with Compressed Reinforcement Plies // Int. Appl. Mech. 2015. Vol. 51. No. 5. P. 561-566.

10. Guz A.N., Kokhanenko Yu.V. Edge Effects in Composites // Int. Appl. Mech. 1995. Vol. 31. No. 3. P. 165-181.

11. Horgan C.O., Carlsson L.A. Saint-Venant End Effects for Anisotropic Materials // Comprehensive Compos. Mater. II. 2018. Vol. 7. P. 38-55.

12. Khimich A.N., Dekret V.A., Popov A.V., Chistyakov A.V. Numerical Study of the Stability of Composite Materials on Computers of Hybrid Architecture // Journal of Automation and Information Sciences. 2018. Vol. 50. No. 7. P. 7-24.

13. Kokhanenko Yu.V., Bystrov V.M. Edge Effect in a Laminated Composite with Longitudinally Compressed Laminas // Int. Appl. Mech. 2006. Vol. 42. No. 8. P. 922-928.

14. Pissanetzky S. Sparse Matrix Technology. London: Academic Press, 1984. 321 p.

15. Soutis C., Guz I.A. Fracture of layered composites by internal fibre instability: Effect of interfacial adhesion // Aeronout J. 2006. Vol. 110. No 1105. P. 185-95. 
16. Tullini N., Savoia M. Decay rates for Saint-Venant end effect for multilayered orthotropic strip // Intern. J. Solids Struct. 1997. Vol. 34, No. 33-34. P. 4263-4280.

17. Tullini N., Savoia M., Horgan C.O. End effect in multilayered strips with imperfect bonding // Mechanics of Materials. 1997. Vol. 26. No. 1. P. 23-34.

18. Wijeyewickrema A.C., Keer L.M. Axial decay of stresses in a layered composite with slipping interfaces // Composite Eng. 1994. Vol. 4. No. 9. P. 895-899.

19. Wijeyewickrema A.C. Decay of stresses induced by self-equilibrated end loads in a multilayered composite // Int. J. Solids Struct. 1995. Vol. 32. No. 3/4. P. 515-523.

УДК 539.3

В. М. Быстров, канд. фриз.-мат. наук, В. А. Декрет, д-р фриз.-мат. наук, В. С. Зеленский, канд. ффиз. -мат. наук

\section{КРАЕВОЙ ЭФФЕКТ В СЛОИСТОМ КОМПОЗИТНОМ МАТЕРИАЛЕ ПРИ НЕСОВЕРШЕННОМ КОНТАКТЕ МЕЖДУ СЛОЯМИ}

С применением уравнений теории упругости кусочно-однородных тел и количественного критерия затухания краевого эффекта исследован краевой эффект В окрестности поверхностной нагрузки слоистого композитного материала. Рассмотрен случай несовершенного контакта между слоями, который моделируется периодической системой межслойных трещин в виде математического разреза. Использована расчетная модель для граничных условий на боковых сторонах многослойного образца из композитного материала, которые соответствуют условиям симметрии. Исследовано влияние размера трещин на длину затухания краевого эффекта. Для численного решения задачи использован метод сеток на основе модифицированного вариационно-разностного подхода. В рамках вычислительного эксперимента применены последовательный и параллельный алгоритм метода Холецкого для решения системы линейных алгебраических уравнений.

Ключевые слова: слоистый композитный материал; несовершенный контакт; поверхностная нагрузка; краевой эффрект; плоская задача теории упругости; количественный критерий затухания краевого эфоректа; метод сеток; параллельные вычисления.

UDC 539.3

\section{M. Bystrov, PhD (Phys.-Math.), V. A. Dekret, Dr. Sci. (Phys.-Math.), V. S. Zelenskii, PhD (Phys.-Math.) \\ END EFFECT IN LAYERED COMPOSITE MATERIAL WITH IMPERFECT CONTACT BETWEEN LAYERS}

Using the equations of the theory of elasticity of piecewise-homogeneous bodies and a quantitative criterion for attenuation of the edge effect, the edge effect in the vicinity of the surface load of a layered composite material is investigated. The case of imperfect contact between layers is considered, which is modeled by a periodic system of interlaminar cracks in the form of a mathematical cut. A computational model was used for the boundary conditions on the lateral sides of a multilayer specimen made of a composite material, which correspond to the symmetry conditions. The influence of the crack size on the decay length of the edge effect is investigated. For the numerical solution of the problem, the grid method is used 
based on a modified variational-difference approach. In the framework of the computational experiment, a sequential and parallel algorithm of the Cholesky method was applied to solve a system of linear algebraic equations.

Keywords: laminated composite material; imperfect contact; surface loading; edge effect; plane problem of the theory of elasticity; quantitative criterion for the extinction of edge effect; mesh method; parallel computations.

When designing, calculating, and testing composite materials (CM), it is of interest to study the joint influence of such factors as the structural heterogeneity of the $\mathrm{CM}$ and the conditions of loading and fixing of structural elements with $\mathrm{CM}$. In many works related to the study of the effect of $\mathrm{CM}$ inhomogeneity on the decay of end effects, it is noted that the length of the zone of end effects at a certain ratio of elastic and geometric properties of material components can reach large values [1, 2, 6, 8 - 11, 16 - 19]. This imposes a significant limitation on the traditional application of the Saint-Venant principle in the design and calculation of structures with KM. Weakening of the adhesion between the components of the CM due to such defects as delamination and disbond, cracks, etc. can lead to a further decrease in the rate of the end effect decay around the local load $[6,7,17,18]$.

The nature of the end effect decay depends on the ratio of geometric parameters that characterize the region of change of external load and structural inhomogeneity of material $[8,9,13]$. Another factor that affects the nature and rate of decay of the end effect are the boundary conditions on the sides of the calculation areas in modeling the problem of determining boundary effects based on equations and methods of elasticity of inhomogeneous bodies [6,9]. Of greatest interest is the case of surface loading, when its significant change occurs at distances comparable to the characteristic size of the structural inhomogeneity of the $\mathrm{CM}$, and the boundary conditions on the sides of the calculation areas are mixed. The case of mixed boundary conditions is the least studied, although this type of conditions most adequately corresponds to composite materials that are modeled by infinite or semi-infinite regions and the decay of the end effect is investigated on the periodicity element of the composite structure $[8,18,19]$. In comparison with the case of stress-free sides of the sample with $\mathrm{CM}$, the imposition of additional bonds in the form of mixed boundary conditions and conditions in displacements on the sides of the calculation area, which include kinematic conditions of one or two components, reduces the end effect zone [6, 9].

Disruption of adhesion between CM components in the presence of interlaminate defects also corresponds to release from bonds in comparison with ideal contact for all types of boundary conditions and requires a study of the nature and quantitative assessment of the end effect. When modeling imperfect contact between the components of the $\mathrm{CM}$, the most common approach is the use of models such as spring-layer model $[6,7,17]$, when along the entire interlaminate contact line is given a proportional relationship between the jump of displacements and tangential tractions. Another approach may be to apply boundary conditions in the areas of the contact line of the CM components that correspond to the ideal connection of the 
layers and the defects of interlayer adhesion of different nature. Defects can be represented by either cracks with stress-free surfaces or "defects with connected edges" that correspond to slip conditions when continuity at the interface is retained for normal components only [15, 18].

In this paper effect of an imperfect bond on the stress decay rate for a multilayer representative element with symmetry conditions on the sides of the calculation region is examined in a two-dimensional formulation. An approach is applied, which is based on the use of the relations of the theory of elasticity of inhomogeneous bodies and quantitative criteria for estimating the end effect for the representative element of $\mathrm{CM}$ [8]. Imperfect contact between the central reinforcing layer and the matrix is modeled by a system of interlaminar macrocracks for the case of stress-free surfaces (the classical model), when the mathematical cut simulate cracks regardless of the reasons of their occurrence. The length of macrocracks is comparable with thickness of the reinforcing layers of $\mathrm{CM}$.

The method of grids based on a modified variational-difference approach was used for numerical solution of the problem [2,3]. In the framework of a computational experiment, a sequential and parallel algorithm of the Cholesky method was used to solve a system of linear algebraic equations of large dimension [5].

The results obtained in this work lead to the following conclusion. Modeling of imperfect contact by applying boundary conditions at the contact areas of CM components corresponding to interlayer adhesion defects in the form of macrocracks with traction-free edges allows investigating the effect of adhesion weakening on decay of end effect. The presence of imperfect contact and weakening of adhesion with increasing size of macrocracks leads to an increase in the decay length of the end effect and its slower decay.

\section{REFERENCES}

1. Bystrov V.M. End effect and near-surface buckling in a laminate composite material compressed by a surface load // Dopov. Nac. akad. nauk Ukr. 2019. No 10.

P. 29-37. (in Russian).

2. Golovchan V.T., Guz A.N., Kokhanenko Yu. V., Kushch V.I. Statics of materials. Mechanics of composites: In 12 volumes / Editor-in-Chief A.N. Guz. Vol.1. Kiev: Naukova dumka, 1993. 455 p. (in Russian).

3. Grygorenko Ya.M., Shevchenko Yu.N., Vasilenko A.T. et al. Computational methods. Mechanics of composites: In 12 volumes / Editor-in-Chief A.N. Guz. Vol.11. Kiev: A.S.K., 2002. 448 p. (in Russian).

4. Khimich A.N., Molchanov I.N., Popov A.V., Chistyakova T.V., Yakovlev M.F. Parallel algorithms for solving problems of computational mathematics. Kiev: Naukova dumka, 2008. 247 p. (in Russian).

5. Supercomputer of IC. http://icybcluster.org.ua/ (in Russian).

6. Baxter S.C., Horgan C.O. End Effects for Anti-plane Shear Deformation of Sandwich Structure // J. of Elasticity. 1995. Vol. 40. No. 2. P. 123-164.

7. Benveniste $Y$. On the Effect of Debonding on the Overall Behavior of Composite Materials // Mech. Mater. 1984. Vol. 3. P. 349-358.

8. Bystrov V.M. Analysis of the decay of edge effects in laminated materials on the basis of a representative element // Int. Appl. Mech. 2000. Vol. 36. No 6. P. 826-834. 
9. Bystrov V.M., Dekret V.A., Zelenskii V.S. Numerical Analysis of the Edge Effect in a Composite Laminate with Compressed Reinforcement Plies // Int. Appl. Mech. 2015. Vol. 51. No. 5. P. 561-566.

10. Guz A.N., Kokhanenko Yu.V. Edge Effects in Composites // Int. Appl. Mech. 1995. Vol. 31. No. 3. P. 165-181.

11. Horgan C.O., Carlsson L.A. Saint-Venant End Effects for Anisotropic Materials // Comprehensive Compos. Mater. II. 2018. Vol. 7. P. 38-55.

12. Khimich A.N., Dekret V.A., Popov A.V., Chistyakov A.V. Numerical Study of the Stability of Composite Materials on Computers of Hybrid Architecture // Journal of Automation and Information Sciences. 2018. Vol. 50. No 7. P. 7-24.

13. Kokhanenko Yu.V., Bystrov V.M. Edge Effect in a Laminated Composite with Longitudinally Compressed Laminas // Int. Appl. Mech. 2006. Vol. 42. No. 8. P. 922- 928.

14. Pissanetzky S. Sparse Matrix Technology. London: Academic Press, 1984. 321 p.

15. Soutis C., Guz I.A. Fracture of layered composites by internal fibre instability: Effect of interfacial adhesion // Aeronout J. 2006. Vol. 110. No 1105. P. 185-195.

16. Tullini N., Savoia M. Decay rates for Saint-Venant end effect for multilayered orthotropic strip // Intern. J. Solids Struct. 1997. Vol. 34. No. 33-34. P. 4263-4280.

17. Tullini N., Savoia M., Horgan C.O. End effect in multilayered strips with imperfect bonding // Mechanics of Materials. 1997. Vol. 26. No. 1. P. 23-34.

18. Wijeyewickrema A.C., Keer L.M. Axial decay of stresses in a layered composite with slipping interfaces // Composite Eng. 1994. Vol. 4. No. 9. P. 895-899.

19. Wijeyewickrema A.C. Decay of stresses induced by self-equilibrated end loads in a multilayered composite // Int. J. Solids Struct. 1995. Vol. 32. No 3/4. P. 515-523.

Інститут механіки

ім. С. П. Тимошенка НАН України,

Київ, Україна

Надійшла до редколеаії 15.08.2021 